\section{RAZVIJANIE UČNEGA STILA V IZOBRAŽEVANJU ODRASLIH}

\section{Razmerje med učnim stilom in osebnostno rastjo}

$\mathbf{V}$

ečina izobraževalcev odraslih bi rada svoje delo dobro opravljala in nenehno izboljševala svoj učni stil.

Temeljni pogoj za kakršnekoli izboljšave pa je, da najprej dodobra razumejo svoje vedenje, kajti prav vedenje $\mathrm{v}$ marsičem vpliva na poučevanje.

\section{PROCES RAZVOJA UČNEGA STILA}

Izboljšave lahko dosežemo na tri načine: s poizkusi in napakami, opazovanjem drugih ali študijem literature (Knox, 1986).

Splošen namen procesa je zagotoviti posamezniku možnost, da pridobi informacije o samem sebi, da te informacije oceni in reagira $\mathrm{v}$ skladu $\mathrm{z}$ oceno in tako postane bolj notranje konsistenten. Proces razvoja učnega stila vključuje tri stopnje: raziskovanje, refleksijo in uporabo.

\section{Raziskovanje}

Vključuje aktivnosti, kot so odkrivanje, imenovanje, oblikovanje, definiranje, razvrščanje in kategoriziranje.Večino aktivnosti pomeni raziskovanje in zbiranje informacij ter interpretacija teh informacij.

Na primer, izobraževalec odraslih nekritično prevzame prepričanja o vlogi učitelja in jih razvrsti, ne da bi jih ovrednotil (na primer prav-narobe, slabo-dobro-zastarelo). Razi- skovanje dejanskega učnega vedenja obsega opisovanje, zbiranje, imenovanje, združevanje itd.

\section{Refleksija}

Obsega preučevanje informacij, ki smo jih zbrali o naših prepričanjih in vedenju. Aktivnosti, kot so spraševanje, primerjanje, eksperimentiranje, premišljevanje, zbiranje in vrednotenje, pomagajo učitelju oblikovati intuicijo, prepričanja in vedenje. Refleksija nam lahko pomaga doseči večjo kongruenco prepričanja in vedenja. Ali mislim drugače, kot delam? Ali verjamem, dosledno ocenjujem in reagiram?

Refleksija zahteva čas in nujno vključuje v učenje odraslih tudi izkušnje. Brez izkušenj

Refleksija
nujno
vključuje
izkušnje.
lahko refleksija poteka le na akademski ravni in primerja eno teorijo z drugo. Cilj refleksije je primerjava teorije $\mathrm{s}$ prakso, prepričanja $\mathrm{z}$ vedenjem, razumevanja $\mathrm{z}$ delovanjem. Refleksija omogoča most med učiteljevim tehničnim znanjem in strokovnimi zmožnostmi (Schon, 1987).

\section{Uporaba (aplikacija)}

Šele uporaba omogoča, da neskladja izginejo in da prepričanje ter vedenje postaneta enotna. Učitelj je pripravljen integrirati novo ve-
Antonija Jakop Srednješolski center $v$ Velenju 
denje v svoj učni repertoar. Novo aktivnost smo raziskali, o njej smo razmišljali in sedaj je postala tako rekoč nov del učiteljeve osebnosti.

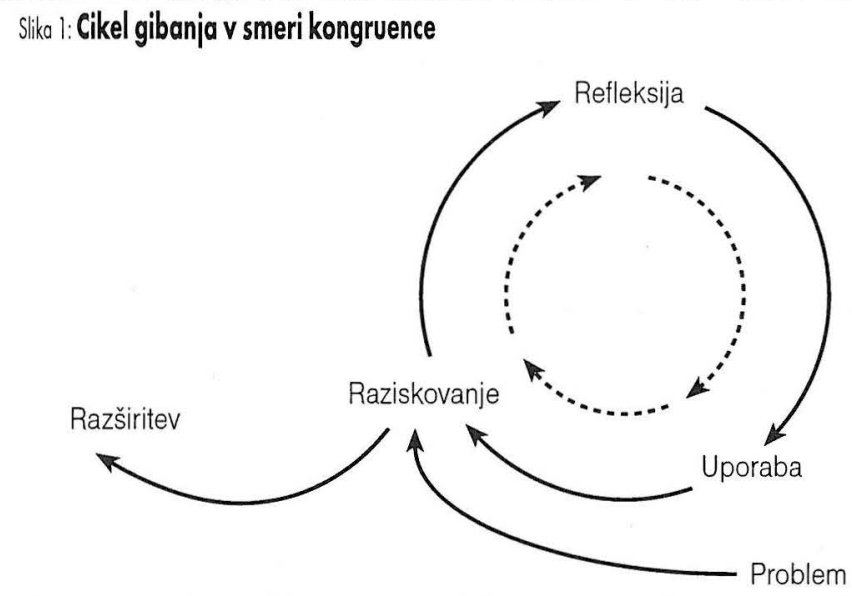

Koncept osebnostne rasti na podlagi refleksije $v$ teoriji izobraževanja odraslih ni nekaj novega. Nasprotno, večina učiteljev pogosto uporablja proces akcijske refleksije oziroma razmišljanja ob dejavnosti - »reflection-inaction « (Schon, 1987, 26). To pomeni takojšen premislek o akciji, da bi sproti preoblikovali še akcijo oziroma rešili nepričakovane probleme. Soroden proces opisuje tudi Brookfield $(1990,50)$. Imenuje ga igra akcije in refleksije (the interplay between action and reflection) in meni, da ga učitelji uporabljajo $\mathrm{v}$ mnogih učnih situacijah, da bi poenostavili učenje.

Kadarkoli govorimo in razmišljamo o znanju,

Da informacija postane znanje, je potreben določen refleksijski čas. Znanje je struktura konceptov in povezav, ki so zgrajene na podlagi reflektiranja pridobljenih informacij. Vsakršne izkušnje sodelovanja, opazovanja, branja, razmisljanja lahko postanejo del posameznikovega znanja. Del znanja pa bodo postale le, če oseba o njih razmišlja in če jih razume (Ebel, $1965,377)$. se moramo zavedati tega: preden izkušnja postane znanje, je potreben določen čas za razmišljanje (refleksijo).

Čeprav je večina učiteljev najbrž seznanjena $\mathrm{z}$ refleksijo, se $\mathrm{v}$ praksi pojavljajo številni problemi. Ovire, kot so čas, številne odgovornosti (sem $v$ treh komisijah, poučujem $\mathrm{v}$ več večernih šolah), omejen »know-how «, morda lahko razložijo, zakaj toliko učiteljev operira s strokovnim znanjem brez poučevalne umetnosti (Schon, 1987, 22).

$\mathrm{Z}$ drugimi besedami, izobraževalci odraslih imajo lahko strokovno znanje, lahko tudi konceptualno razumejo, kako to znanje uporabiti v tipični situaciji. Toda tipičnih situacij je vse manj. Poučevanje odraslih postaja vse bolj unikatno, neznanih situacij je vse več. Večina izobraževalcev odraslih ni usposobljena, da bi $\mathrm{v}$ takšnih situacijah uporabila »umetnost uokvirjanja problema, umetnost uvedbe in umetnost improvizacije«. To je namreč potrebno za dobro povezavo teorije s prakso in uporabo učnih tehnik (Schon, 1987, 13).

Prav na podlagi procesa razvoja učnega stila, ki obsega raziskovanje, reflektiranje in uporabo, lahko izobraževalci odraslih pridobijo nujne informacije o samem sebi. Tako lahko prekrijejo svoje strokovno znanje s skorjo umetnosti in izboljšajo svoj učni stil.

\section{UČNI STIL IN PROCES OSEBNOSTNE RASTI}

Če pregledamo vse definicije in se ozremo na nekatere besede, kot so konstrukt, paradigma, značilnosti, kvaliteta, lahko vidimo, da se te definicije nanašajo na učni stil kot na nekaj večdimenzionalnega, dinamičnega, ki vsebuje še načrtovano logiko organizacije.

Pri raziskovanju lastne notranjosti bomo našli globoko varovane vrednote, prepričanja in stališča, ki vplivajo na naše vedenje in bivanje. Apps $(1989,17)$ opisuje rezultate takšnih notranjih potovanj kot razumevanje temeljev 
Učni stil in osebnostna rast sta nedvomno povezana. Učni stil se lahko različno izraža: kot hipotetiéni konstrukt (Fischer \& Fischer, 1979, 251), kot vsota osebnih drž, potez in vedenja, kot $\gg$ medij $k$, ki oddaja podatke (Huelsman, 1983, 15), in kot vsota vsesplošnih značilnosti in kvalitet, ki jh ućitelj oddaja $v$ ućlnici in ki so združljive v različnih situacijah (Conti, 1990, 3).

naše osebnosti in meni, da lahko oblikujemo različne učne odločitve, če se zavedamo, v kaj verjamemo in kaj cenimo. Od kod pridejo ti temelji naše osebnosti? »Vsi imamo neke temelje, na podlagi katerih delujemo. Ti izhajajo še iz otroštva, iz šole, iz socialnega okolja, v katerem smo odraščali in od pomembnih avtoritet (pomembni Drugi), s katerimi smo navezali medosebne kontakte.« (Apps, 1989, 17)

Če so torej izobraževalci odraslih motivirani in želijo resnično izboljšati svoje delo, je pomembno, da načrtujejo svoj lastni proces rasti. Identifikacija vrednot, prepričanj, stališč in vedenja, ki skupaj sestavljajo učni stil učitelja, lahko zagotavlja notranji pogled $\mathrm{v}$ to, kar smo kot osebnost, in kje začeti.

Preučevanje samega sebe ni pomemben proces samo za individualno rast učitelja, ampak lahko pomembno pripomore tudi $\mathrm{k}$ vrednotenju učiteljskega poklica (Conti, 1990). Eden temeljnih razlogov, da je poklic učitelja nenehno pod drobnogledom in da je pravzaprav izgubil nekdanji ugled, je, da »učitelji kot skupina niso sposobni jasno povedati in zagovarjati svojih prepričanj, spoznanj in izkušenj z učenjem in poučevanjem «(Conti, 1990, 79).

Vprašanja, ki se lahko uporabijo kot izhodiščna točka za oblikovanje filozofije učnih stilov, so: »Kakšen je moj pogled na učence? Kaj je namen učnega načrta? Kakšna je vloga učitelja? Kakšno je moje poslanstvo pri posredovanju znanja?«(Conti, 1990, 79)

\section{DVA NAČINA OSEBNOSTNE RASTI ZA IZOBRAŽEVALCE ODRASLIH}

V nadaljevanju sta opisana dva specifična načina rasti, ki vplivata na učni stil in lahko zagotovita doživljenjsko notranje odkrivanje samega sebe ter tudi zunanjega delovanja. Pojma, ki označujeta ta dva načina rasti, sta:

- gibanje v smeri kongruence (movement toward congruence), poudarjanje vrednot, prepričanj, stališč in vedenja;

- razširitev (expansion), ki sega prek trenutnih prepričanj, veščin, sposobnosti, navad in preferenc do bolj zaželenega delovanja.

Do gibanja v smeri kongruence pride na podlagi pogleda $\mathrm{V}$ lastno notranjost in namernih sprememb (biti boljši učitelj). $\mathrm{V}$ procesu razširjanja pa primerjamo lastnosti, stališča umetnosti učenja in poučevanja ali želenih lastnosti drugih

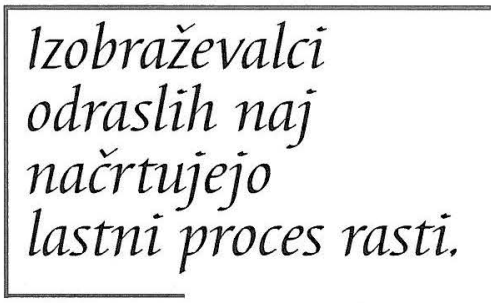
izobraževalcev odraslih in nato izvedemo (namerne) spremembe.

Na sliki 2 je prikazano razmerje med kongruenco in razširitvijo. Oba tipa rasti dopolnjujeta drug drugega, njune notranje in zunanje povezave pa pomenijo poseben način harmonije ali ritem. Ritem procesa osebnostne rasti omogoča, da je stil poučevanja dinamičen in življenjski.

\section{Slika 2: Razmerje med kongruenco in razširiivijo}

\section{Kongruenca:}

»biti tako dober učitelj,

kot sem v tem času lahko«
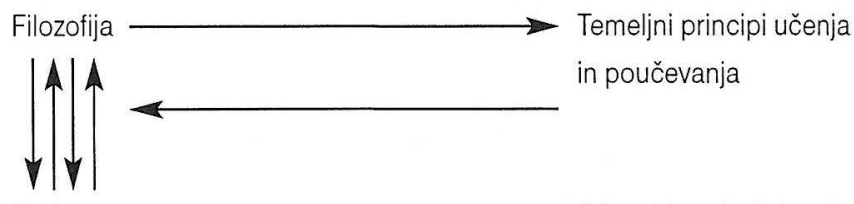

Vedenje

\section{Razširitev:}

„najboljši učitelj, kot bom kdaj lahko postal « in poučevanja

Primeri in zgledi drugih izobraževalcev odraslih 


\section{GIBANJE V SMERI KONGRUENCE}

Bolj ko so vrednote, prepričanja in stališča povezani $\mathrm{z}$ vedenjem, bolj kongruenten je učni stil in boljši je lahko učitelj. Prav ta skladnost omogoča uspešno delo.

Gibanje v smeri kongruence je posebna vrsta sinergije, v kateri se združijo različne osebnostne lastnosti in pomenijo več kot le seštevek teh lastnosti, novo vrednost. Če ločeno gledamo posamezne dele, so vedno nepopolni. Prather meni $(1980,123)$ : »Če ga gledamo posamično, vsak del telesa na prvi pogled potrebuje popravek. «Prav tako učni stil temelji na posameznih osebnostnih lastnostih, ki so veliko več kot le vsota teh lastnosti, če so povezane. Sinergijski procesi potekajo na podlagi preučevanja vrednot, prepričanj in stališč ter vedenja, ki ga vključu-

Učni stil je vsota posameznikovih osebnostnih drž. je posamezni učni stil. Če pride do konflikta med posameznimi stališči, pride do stagnacije v razvoju učnega stila.

Gibanje v smeri kongruence lahko pospeši že pogovor med izobraževalcem in študenti. Mnogo učiteljev priznava, da je vključevanje študentov $v$ delo pomembno za učno izmenjavo, še posebej, če so študenti odrasli ljudje.

Po daljšem razmišljanju o osebnih prepričanjih, vrednotah lahko posameznik ugotovi, da se ne vede $\mathrm{v}$ skladu s prepričanji, ki so globoko v njem. Ko se to zgodi, se je posameznik prisiljen ponovno ozreti $v$ vlogo učitelja, podobno, kot to počne v vlogi staršev. Večinoma smo bili vzgojeni v prepričanju, da starši najbolje vedo, kaj otroci potrebujejo, in da ti sploh ne potrebujejo lastnih izkušenj. Vlogo staršev nekritično prenesemo na vlogo učitelja tudi, kadar gre za odnos med odraslimi, torej v izobraževanju odraslih. To pomeni, da jim kratimo pravico do lastnih izkušenj. Te pa so ena izmed pomembnih značilnosti, po ka- terih se izobraževanje otrok razlikuje od izobraževanja odraslih.

Naša prepričanja vplivajo na to, kar delamo, ne da bi se tega zavedali (Apps, 1989, 17).

Največja nevarnost za razvoj učnega stila v izobraževanju odraslih se skriva v tem, da nekateri učitelii še vedno ostajajo v vlogi staršev, namesto da bi se identificirali s kulturo študentov. To pa vpliva na hierarhičnost med učiteljem in študenti, s čimer si želi učitelj pridobiti večjo moč in nadzor nad njimi. In, če v izobraževanju odraslih velja, da sta učitelj in študent enakovredna in želita enakovredno sodelovati, se morajo taka hierarhična razmerja nujno umakniti sodelovanju.

Vprašanje je, kaj je treba spremeniti: naše vedenje, naše notranje prepričanje ali prepričanje o našem poklicu. Spreminjanje prepričanja, iz katerega izhaja sprememba vedenja, je dolgotrajen in zahteven proces.

V izobraževanju odraslih mora učitelj zniževati raven nadzora $\mathrm{v}$ učilnici s ciljem porazdelitve moči. Šele ko postane prepričanje o delitvi moči temeljno in del življenjske filozofije, se to lahko manifestira $\mathrm{v}$ boljšem učnem stilu. Če se namreč izobraževalci odraslih ne vedejo v skladu s svojimi prepričanji in stališči, onemogočijo, da bi učni stil postal kaj več kot le seštevek posameznih lastnosti. Le tisti učitelji, ki prepoznajo svoja temeljna prepričanja in svoje vedenje ter si prizadevajo, da bi jih med seboj uskladili, lahko osebnostno rastejo. $\mathrm{S}$ procesom raziskovanja, refleksije in uporabe so povezani vzponi in padci, ki silijo učitelja k osebnostni rasti, uspehu ali pa tudi $\mathrm{k}$ stagnaciji.

\section{RAZŠIRJANJE}

Čeprav zveni mehansko, je ekspanzija v resnici organski proces rasti skozi spiralo notra- 
njega raziskovanja in zunanjih primerjav. Ko učitelj dovolj dobro spozna svoja prepričanja, vrednote, stališča in vedenje ter doseže raven notranje skladnosti in udobnosti, je njegov naslednji izziv, da skozi osebnostno rast v stilu poučevanja ponovno ovrednoti učni stil z uporabo zunanjih standardov primerjave.

Za vseživljenjsko osebnostno rast ni dovolj le skladnost učnega stila. Učitelj mora imeti svoj učni stil rad in ga sprejemati tudi, če ga primerja s stili drugih ali s trenutno aktualnimi stili poučevanja. O razširitvi lahko govorimo takrat, kadar učitelj preizkusi različne možnosti in se skuša odločiti ter sprejeti novo prepričanje, ki vpliva na njegovo vedenje.

Učitelji so pogosto zadovoljni z znanjem o določeni veščini, niso pa povsem zadovoljni z rezultati posredovanja znanja. Kadar gre za takšne okoliščine, je dobro, če je učitelj kongruenten s svojimi stališči, vendar hkrati dovolj pogumen, da poskusi kaj novega, drugačnega in izzivalnega. Novo lahko pomeni premislek o načinu podajanja veščin. Drugačno lahko pomeni uporabo popolnoma drugačne tehnike $\mathrm{v}$ podobnih okoliščinah, izzivalno pa spraševanje o celotnem pristopu $\mathrm{k}$ okoliščinam.

V nadaljevanju navajam zgodbo inštruktorja v osnovni šoli za odrasle, ki je želel vsako učno uro izvesti drugače. Bil je sramežljiv in ni bil vajen ustaljenih začetnih pogovorov $\mathrm{v}$ razredu: »Dober večer, dobrodošli v razredu. Kako ste kaj? « Njegov tipični začetek ure je bil: $\gg V$ redu, pa začnimo.« Njegovo vedenje je ustrezalo trenutnemu prepričanju (tu smo, da nekaj naredimo, zato začnimo). Toda čez čas se mu takšen začetek učne ure ni zdel več primeren. Kar je potreboval, je bila sposobnost razširiti svojo izbiro. Po pogovoru z ravnateljem (»Kako začneš uro? Lahko pridem pogledat? «) in popoldnevu, prebitem $\mathrm{v}$ knjižnici, kjer je pregledoval učne metode, je lahko razširil učni repertoar (Heimlich \& Norland, 1994, 12).
Širitev lahko pride le iz nas samih. Učni stil ni obleka, je bolj okrasek, modni dodatek. Učni stil prihaja iz: »Kdo sem jaz?«, zato mora potekati od: »Vse, kar sem bil.« proti: »Vse, kar bom kadarkoli lahko.« Širitev vključuje izkušnje s poučevanjem. Modrost je kombinacija znanja in selekcija tega znanja na podlagi izkušenj (Heimlich \& Norland, 1994, 13).

Širitev omogoča, da učitelji vidijo tudi zunaj sebe in $\mathrm{z}$ izkušnjami spreminjajo učni stil. Teorije o kakovosti izobraževanja odraslih, preizkušena načela poučevanja in učenja, mentorski ali vodstveni način, vzoren učitelj lahko služijo kot zunanja primerjava. Proces preučevanja samePri samovrednotenju učnega stila uporabimo zunanje standardne primerjave. ga sebe (usklajevanje prepričanj in vedenja) in nato zunanja primerjava (pogled zunaj sebe in razvrščanje vrednot na novo) privedeta učitelja do razvoja edinstvenega, le njemu lastnega učnega stila.

\section{ZAČETEK PROCESA RASTI}

Nenehno izobraževanje učiteljev je pomembno za moralo, izboljšanje veščin, posodabljanje vsebine, obvladovanje stresa in preprečevanja izgorevanja na delovnem mestu. Vendar je za nadaljnje izobraževanje učiteljev značilno, da je to čestokrat igra na srečo, da je slabo povezano s potrebami učitelja in da ga ne podpira pri delu. Toda količina in kakovost nadaljnjega izobraževanja se lahko povečata s spodbujanjem izobraževalcev odraslih, da vodijo lastno nadaljnje izobraževanje. To pomeni, da so kreatorji svojega nadaljnjega izobraževanja.

Da bi postal proces rasti formalna aktivnost, se morajo izobraževalci odraslih najprej strinjati, da so sami odgovorni za svojo usodo, da prepoznajo svoje specifične potrebe, da imajo podporo administracije, svojih 


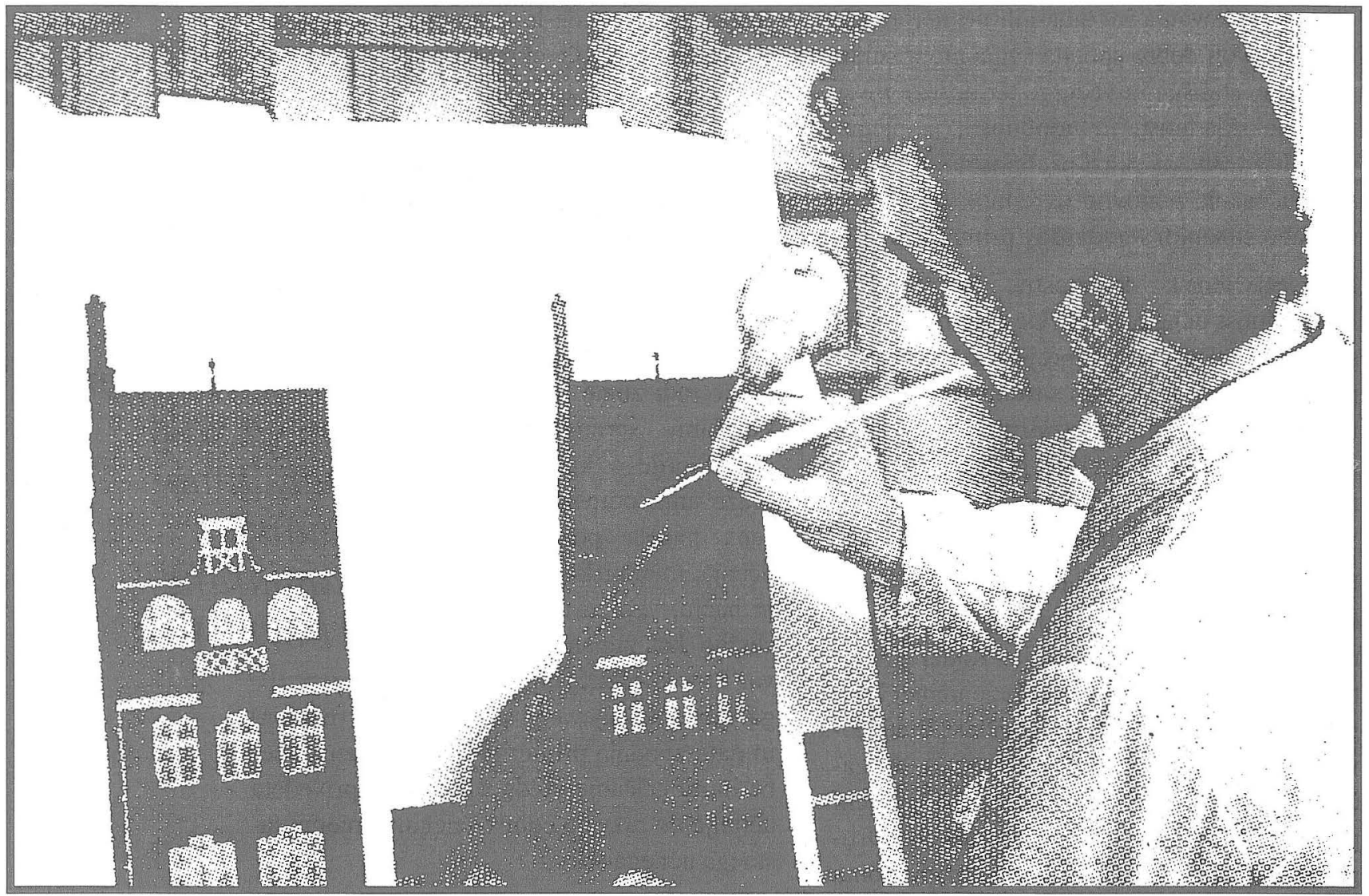

nadrejenih in poklicnih kolegov (Bowes, Smith, 1986). Bowes in Smith (1986, str. 10) predlagata povezavo koncepta vseživljenj-

Kakovost izobraževanja odraslih je odvisna tudi od izobraženosti izobraževalcev odraslih. skega učenca s pripravljenostjo za to aktivnost in podporo drugih. Ko učitelj nadzoruje prva dva, se lahko loti še iskanja podpore.

Florini (1989), Brookfield (1990) in drugi so predlagali napotke za začetek raziskovanja učnega stila. Florini izjavlja, da so samorefleksija, vrednotenje s strani študentov, videoposnetki lastnega poučevanja in opažanja poklicnih kolegov zelo pomembni viri podatkov za oblikovanje učnega stila (str. 51). Zapomnimo si, da te tehnike uporabljamo večinoma za opazovanje vedenja $\mathrm{v}$ učilnici - za predstavi- tev in morebitno izboljšanje le enega dela stila poučevanja.

Conti (1990) razpravlja o sorodnem pristopu akcijske refleksije, ki temelji na »razmišljanju hoteti, vedeti več« kot osnovni ideji znanja. Vrsto znanja, pridobljenega $\mathrm{z}$ akcijsko refleksijo, ki ga je opisal Schon (1987), Conti razlaga takole: »Nepredvidljive situacije silijo praktike, da razmišljajo na povsem nov način. Razčleniti morajo probleme, s katerimi se dnevno soočajo, in zgraditi nov način spopadanja $\mathrm{z}$ njimi. $Z$ uporabo osnovnega znanja in izkušenj so sposobni reševati nove situacije. Ko razmišljajo o svojem odzivu na te situacije, pridobijo novo znanje za prihodnje akcije.« (str. 80)

Ta opis pomeni spiralni način razvoja učnega stila (slika 3). Raziskava, refleksija, uporaba in osebnostna rast zagotavljajo, da izobraže- 


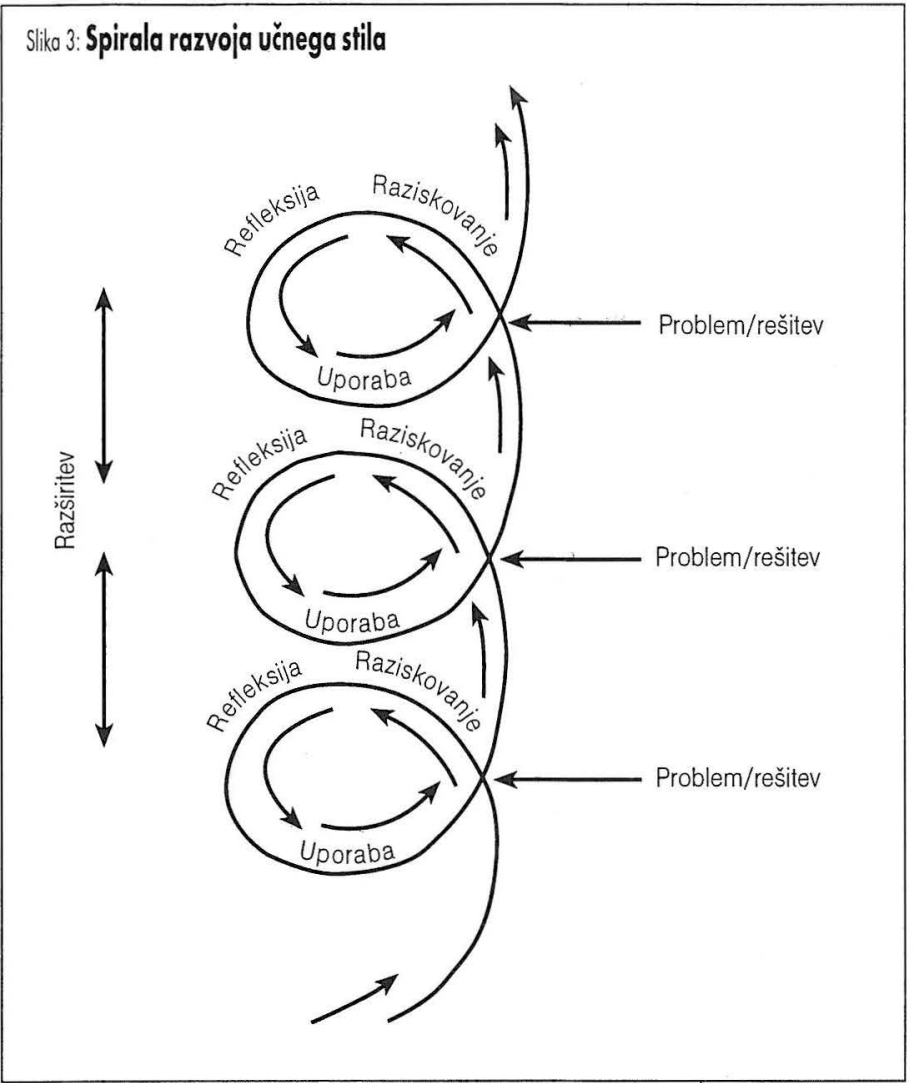

bneje prebije skozi spremembe.

Prva stopnja rasti je, da ugotovimo in sprejmemo, da se gibanje v katerikoli smeri enkrat ustavi. Veliko ljudi misli, da spremembe in osebno rast dosežemo brez gibanja od pozicije počivanja k poziciji premikanja. Spremembe in rast po definiciji povzročajo gibanje. Ko se nekdo vozi z avtomobilom, vidi spremembe. Ko nekdo raste, se mu horizonti in perspektive spreminjajo. Končati eno stvar je nujno za začetek druge.

Načrtovanje razvoja in sprememb nam olajša izbiro. Pomembna stvar, na katero izobraževalci odraslih ne bi smeli nikoli pozabiti, je, da lahko razvijamo učni stil le s skrbnim načrtovanjem in da je to pro-

valec načrtuje znanja, ki jih bo potreboval za svoj nadaljnji razvoj.

$\mathrm{Z}$ uporabo tega procesa lahko učitelji pridobijo nove vrednote, prepričanja in stališča ter razvijejo novo vedenje, primernejše za posebne učne izmenjave.

\section{STOPENJSKI PROCES RASTI}

Začetek procesa rasti je lahko spodbuden, lahko pa je tudi zelo stresen. Začeti en proces pomeni končati drugega. Tako kot so prihajanje in odhajanje, začetek in konec naravni vzorec življenja. Čeprav so del življenja, še ne pomeni, da jih zlahka dosežemo.

Edwin Cole (1987) predlaga večstopenjski proces rasti. Izogibanje težavam $\mathrm{v}$ procesu razvoja učnega stila ne sme biti glavni cilj izobraževalca, zagotovo pa lahko ta stopenjski model uporabi, da se z manj truda in udo-

ces, ki ni nikoli končan. Razviti je treba načrt sprememb in potem delovati v skladu $\mathrm{z}$ njim vse življenje, vendar pravzaprav nikoli ne prispemo na cilj. Velikokrat lahko začetek procesa rasti povzroči krizo. Pomislimo na zakon inercije. Predmet ostane na mestu, dokler se kaj ne zaleti vanj in ga spravi v gibanje. Skrben načrt zagotavlja nadzor osebnostne rasti.

Učitelji se večkrat čutijo nemočne. Študenti, administra-

Učni stil lahko razvijamo les skrbiim načrtovanjem. cija, celo sistem jih ignorirajo in pripravijo do tega, da se sprašujejo o smislu svojega poklica. Lastna vrednost, ustvarjena na podlagi izkušenj in interpretacij, ima pomembno vlogo pri določanju temeljev učiteljevih prepričanj, stališč in vedenja.

Za načrtovanje dela mora učitelj zaupati svojemu učnemu procesu. Zaupanje se krepi sko- 
zi čas in z izkušnjami. Če ni tako, sta za to ponavadi dva razloga:

1. na voljo je premalo časa, da bi se ustvarilo zaupanje;

2. zaradi slabih izkušenj ne zaupamo.

Zaupanje procesu rasti, tako kot vsemu novemu, zahteva čas in izkušnje. Uporabljamo izkušnje drugih, ki so bili $v$ tem procesu rasti uspešni.

\section{ZNANJE O SEBI}

Tipična skrb mnogih učiteljev v zvezi z osebnostno rastjo je odgovornost za povečanje lastnega znanja. Znanje zahteva akcijo oziroma ukrepanje. Ko je pridobljeno, ga je treba uporabiti. Ko učitelji razvijajo učni stil, se pojavi potreba po pridobivanju novega znanja o prepričanjih in vedenju. Tako pridobljeno znanje zahteva odgovornost, da to znanje preudarno uporabimo.

Deljenje znanja s samim sabo je včasih tako imenovano samorazkritje. Ljudje, ki so tega sposobni, so tudi bolj pripravljeni deliti osebne informacije $\mathrm{z}$ drugimi.

Strahove samorazkritja je naštela Haganova (1990):

»Bojim se, da bi se zasovražil, če bi ugotovil, kdo sem v resnici.«

»Bojim se, da sem nepomemben in nezanimiv.«

»Bojim se, da bodo moje laži postale vidne.« »Bojim se ugotoviti kaj strašnega o sebi.«

»Bojim se prisluhniti sebi, ker ne bi nič slišal.« (str. 2).

Trdi, da moramo postati najprej prisrčni sami s seboj, preden imamo lahko prisrčen odnos z drugimi. Ta proces pogosto pretrga strah pred razočaranjem, pred tem, kaj bomo našli, če pogledamo globoko v svojo notranjost. To je lahko strah pred odgovornostjo za pravilno rabo našega znanja.
V resnici pa je moč v informacijah. Več ko veš o sebi, močnejši si. Sebe razkrivaš sam prek zaznav v okolju in reakcij do okolice.

\section{SKLEPNE MISLI}

Ko premišljujemo o sebi kot učitelju, potrebujemo gibalo. Množina osebnostnih karakteristik niha okrog centralne točke. Ko se ena lastnost spremeni, se spremeni tudi celotna vsebina. Ko kot učitelji začnemo rasti, sprožimo različne dele našega gibala. Kot reakcija na to začetno silo, čeprav je še tako prijazna, se lahko pojavi zmeda.

Če hočemo spoznati druge, moramo najprej spoznati sebe. Da bi imeli radi druge, moramo imeti najprej radi sebe. To lahko dosežemo le tako, da smo pripravljeni vložiti v čas, ki je potreben, da spoznamo, kdo smo v resnici. Purkey in Novak (1984) opisujeta vlogo učitelja in menita, da je dobro poučevanje tisto, pri katerem študenti vidijo sami sebe kot sposobne, vredne, samousmerjene in opogumljene, da delujejo v skladu s temi samozaznavami. Nasvete, ki jih delimo njim, uporabimo tudi zase. Moramo se videti sposobne, vredne in usmerjene vase. Da tako ravnamo, moramo v resnici vedeti, kdo smo, kakšne so naše vrednote, prepričanja, stališča, filozofija in vedenje. So skladni? Od kod prihajajo? Jih izboljšujemo? Če jih ne, kaj želimo spremeniti? Kako bo spreminjanje enega elementa vplivalo na druge? In končno, kaj ta proces pomeni za nas kot učitelje?

Izobraževalci odraslih, ki želite izboljšati učni stil v smeri večje kongruence, lahko začnete tako, da na listu papirja napišete vaše osebne vrednote, prepričanja, stališča in filozofijo. Ne spuščajte se v podrobnosti. Samo zapišite samopredstavitev, tako kot bi odgovarjali na zaposlitveni intervju za službo učitelja. Vključite svoja prepričanja, stališča in filozofijo o izmenjavi učenja in poučevanja. So predstavitve podobne? 
Poskusite to napisati nekaj tednov ali mesecev kasneje. Kaj se je spremenilo? Zakaj? Vidite rast? Je vaša predstavitev globlja, osebnejša, pozitivnejša, jasnejša? Ste zadovoljni z razliko? Bi rekli, da ste se v resnici spremenili? Ali ste pridobili samo več informacij o sebi ? Kakorkoli, odgovori niso tako pomembni, kot je pomemben sam proces spraševanja. $\mathrm{V}$ tem primeru je proces pomembnejši od odgovorov.

\section{LITERATURA}

Apps, J. W. (1989). Fondutaion for effective teaching. V: E. R: Hayes (Ed.). Effective teaching stiles, str. 17-28. San Francisco: Jossey-Bass.

Bowes, S. G. \& Smith, R. M. (1986). Directing your own continuing education. Lifelong Learning 9 , str. 8-10.

Brookfield, S. D. (1990). The skillful teacher: On technique, trust and responsiveness in the classroom. San Francisco: Jossey-Bass.

Cole, E. L. (1987). Entering crisis and leaving. Tulsa, Ok.: Honor Books.

Conti, G. J. (1990). Identifying your teaching style. V: M. W. Galbraith (Ed.) Adult learning Methods, str. 79-90. Malabar.

Ebel, R. L. (1965). Measuring educational achievement. Englewood Cliffs, NY: Prentice Hall

Ficher, B. \& Ficher, L. (1979). Styles in teaching and learning. Education Leadership, 34, 251.

Florini, B. M. (1989). Teaching styles and technology. V: E. R. Hayes (Ed.). Effective teaching stiles, str. 41. San Francisco: Jossey-Bass.

Hagan, K. L. (1990). Internal affairs - A journal keeping workbook for self intimacy. New York: Harper \& Row.

Heimlich, J. E. \& Norland, D. J. (1994). Measuring teaching styles. Doctoral dissertation. Ohio State University.

Huelsman, J. M. (1983). An exploratory study of the interrelationships of preferred teaching styles, preffered learning styles, psychological types and other selected characteristics of secondary teachers. Doctoral dissertation. Ohio State University

Kettelhack, G. (1984) The wit and wisdom of Quentin Crisp. New York: Harper \& Row.

Knox, A. B. (1986). Helping adults learn. A guide to planning, implementing, and conducting programs. San Francisco: Jossey-Bass.
Prather, H. (1980). There is a lace where you are not alone. Garden City, NY: Doubleday.

Purkey, W. W. \& Novak, J. M. (1984). Inviting school success: A self-concept approach to teaching and learning. Belmont, CA: Wadsworth.

Schon, D. A. (1987). Educating the reflective practitioner. San Francisco: Jossey-Bass. 